\title{
Prediksi Angka Kelahiran Bayi Pada Desa Tridaya Sakti Dengan Menggunakan Algoritma Naive Bayes
}

\author{
Nur Isnaini Parihah ${ }^{1 * *}$, Sari Hartini ${ }^{1}$, Juarni Siregar ${ }^{1}$ \\ *Korespondesi: e-mail: nurisna0203@nusamandiri.ac.id
}

${ }^{1}$ Program studi Teknik Informatika, STMIK Nusa Mandiri Jakarta; Jalan Kramat Raya No.18, Kwitang, Kec. Senen, Kota Jakarta, Daerah Khusus Ibu Kota Jakarta (021) 88985613 ,

e-mail: nurisna0203@nusamandiri.ac.id sari.shi@nusamandiri.ac.id, juarni.jsri@nusamandiri.ac.id

Submitted: 5 Oktober 2020

Revised: 26 Oktober 2020

Accepted: 9 November 2020

Published: $\mathbf{3 0}$ November 2020

\section{Abstract}

The birth rate is something that can affect the increase in population growth. Large population is a burden for development. According to Malthus's Theory which states that a large population growth is not the welfare that is obtained but rather poverty will be encountered if the population is not well controlled. The number of baby births in Tridaya Sakti Village is increasing every year. Therefore Data Mining using the Naive Bayes algorithm can help in the calculation of predicting infant birth rates in Tridaya Sakti Village. Data Mining in predicting the number of infant birth rates aims to determine the number of infant birth rates for the coming year using the Naive Bayes algorithm. By looking at the prediction patterns of each variable and testing training data on testing data. It is hoped that the Naive Bayes algorithm can solve the problem in Tridaya Sakti Village in handling and overcoming the calculation of infant birth rates and can help the Tridaya Sakti Village in regulating population growth in the coming years. The results obtained from the data that have been taken and calculated by Data Mining using the Naive Bayes algorithm produce an information that can be used as a reference to find out the number of births. Performance and time in data processing are more effective and efficient as well as more accurate and accurate predictions of the number of baby births.

Keywords: Naive Bayes, Birth of a Baby, Prediction

\section{Abstrak}

Angka kelahiran merupakan suatu hal yang dapat mempengaruhi peningkatan pertumbuhan penduduk. Jumlah penduduk yang besar merupakan beban bagi pembangunan. Menurut Teori Malthus yang menyatakan bahwa pertumbuhan jumlah penduduk yang besar bukanlah kesejahteraan yang didapat tapi justru kemelaratan akan ditemui bilamana jumlah penduduk tidak dikendalikan dengan baik. Jumlah angka kelahiran bayi di Desa Tridaya Sakti setiap tahunnya semakin bertambah. Maka dari itu Data Mining dengan menggunakan algoritman Naive Bayes dapat membantu dalam perhitungan memprediksi angka kelahiran bayi di Desa Tridaya Sakti. Data Mining dalam memprediksi jumlah angka kelahiran bayi bertujuan untuk mengetahui jumlah angka kelahiran bayi tahun yang akan mendatang mengunakan algoritma Naive Bayes. Dengan melihat pola prediksi dari setiap variabel dan melakukan pengujian data training terhadap data testing. Diharapkan algoritma Naive Bayes ini dapat menyelesaikan permasalahan di Desa Tridaya Sakti dalam menangani dan mengatasi perhitungan angka kelahiran bayi dan dapat membantu pihak Desa Tridaya Sakti dalam mengatur pertumbuhan jumlah penduduk tahun yang akan mendatang. Hasil yang diperoleh dari data yang sudah diambil dan dihitung dengan Data Mining mengunakan algoritam Naive Bayes menghasilkan sebuah informasi yang dapat digunakan sebagai acuan untuk mengetahui jumlah angka kelahiran bayi. Kinerja 


\section{Pendahuluan}

Perkembangan yang sangat pesat saat ini dimulai dari penemuan informasi baru pada data yang sangat besar dengan mencari suatu pola tertentu istilah dari Data Mining (Idris, 2019). Data Mining sering digunakan sebagai penelitian untuk pola penjualan, penentu jumlah produksi, keterkaitan pelanggan, dan lain-lain. Penelitian yang dilakukan untuk kepentingan pemerintah tentang kependudukan dalam program penekanan jumlah penduduk sangat jarang dilakukan. Pada hal penelitian tentang Data Mining dalam pemerintahan sangat diperlukan sebagai bahan informasi bagi pemerintah. Data Mining dapat digunakan untuk penelitiannya tentang kelahiran bayi untuk memprediksi tingkat jumlah angka kelahiran bayi dimasa yang akan datang.

Salah satu faktor penyebab terjadinya kenaikan jumlah penduduk di suatu negara adalah angka kelahiran ditambah dengan teknologi yang semakin canggih bisa membuat kelahiran seorang anak dapat dipercepat, apa bila terjadi terus menerus maka yang akan terjadi ialah kepadatan penduduk (Syahra et al., 2019). Teknologi obat-obatan semakin berkembang sehingga angka kematian menurun sedangkan angka kelahiran tetap tinggi. Hal ini dapat mendorong terjadinya pertumbuhan penduduk yang semakin cepat (Rochaida, 2016).

Persebaran penduduk secara optimal berdasarkan keseimbangan jumlah penduduk dengan daya didukung kualitas masyarakat dan kulaitas lingkungan merupakan harapan pemerintah untuk setiap daerahnya. Permasalahannya adalah tidak semua daerah mengalami keseimbangan jumlah penduduk dan melonjaknya jumlah penduduk di Desa Tridaya Sakti memang perlu diperhatikan. Jumlah kelahiran Bayi di Desa Tridaya Sakti setiap Tahun semakin bertambah. Angka kelahiran yang tinggi perlu perhatian khusus dalam penanganannya. Bentuk perhatian pemerintah menanggulagi angka kelahiran yang tinggi dengan melaksanakan program keluarga berencana (KB) secara komprehensif (Kelahiran, 2017). Pihak UPT DINAS KEPENDUDUKAN menghimbau agar masyrakat melakukan program keluarga berencana (KB) yang membatasi kelahiran 2 anak per-keluarga. Dalam mengatasi masalah tersebut perlu adanya analisis data untuk mengetahui prediksi pertambahan jumlah angka kelahiran bayi pertahunnya.

Salah satu unsur pertambahan penduduk secara alami adalah angka kelahiran. Lahir dalam bidang demografi adalah anak yang benar-benar di lahirkan hidup (Idris, 2019). Angaka kelahiran bayi sebagai indikator yang penting untuk mencerminkan keadaan derajat kesehatan di suatu masyarakat. Jumlah pertumbuhan penduduk yang semakin meningkat disuatu daerah membawa dampak dari sisi aspek kehidupan manusia. Jika pertumbuhan peduduk secara kuantitas tidak di imbangi secara kualitas masyarakat, dapat menimbulkan beban dan masalah bagi pembagunan (Syahra et al., 2019). 
Algoritma Naive Bayes dapat membantu pihak kantor Desa Tridaya Sakti mengetahui tingkat angka kelahin dalam proses mengelola laporan data penduduk. Algoritma Naive Bayes dalam Data Mining dapat membantu petugas kependudukan dalam melakukan evaluasi penentuan angka kelahiran (Idris, 2019). Degan ini dapat melihat angka kelahiran bayi pada Desa Tridaya Sakti yang akan datang sehingga dapat dijadikan acuan untuk menekan jumlah angka kepadatan penduduk pada tahun yang akan datang.

Pembatasan masalah pada penelitian ini yaitu: 1). Hanya membahas penggunaan Data Mining untuk menghitung angka kelahiran bayi. 2). Hanya menganalisis data untuk menghitung angka kelahiran bayi. 3). Data yang dianalisis adalah rekapitulasi pendududk Desa Tridaya Sakti. 4). Analisa ini menggunakan aplikasi RapidMiner. 5). Data yang digunakan data dalam kurun waktu 10 tahun kebelakang. 6).Variabel-variabel yang diambil/digunakan adalah WUS (pasangan usia susbur), Jumlah Penduduk, Angka Kelahiran, Angka Pernikahan, sebagai variabrl terkait.

\section{Metode Penelitian}

Penelitian ini dilakukan di Kentor Desa Tridaya Sakti dibidang kependudukan. Dalam menganalisa data mengunakan perhitungan dengan menggunakan Algoritma Naive Bayes. Naive Bayes mengadopsi teori ilmu statistik yaitu dengan mengunakan teori kemungkinan (Probabilitas) untuk menyelesaikan sebuah kasus Supervised Learning, artinya dalam himpunan data terdapat Label, Class atau Target sebagai acuan. Model Klasifikasi terdapat beberapa fase penyelesaian yaitu dimulai data Training dan diakhiri dengan proses Testing sehingga dihasilkan sebuah keputusan yang akurat (Dicky Nofriansyah, 2015).

Rumus Naive Bayes Tipe Data Nominal (Suntoro, 2019)

$$
P(H \mid X)=\frac{P(X \mid H) \cdot P(H)}{P(X)}
$$

$X$ = Sampel data yang memiliki kelas (label) yang tidak diketahui

$\mathrm{H}=$ Hipotesa bahwa $\mathrm{X}$ adalah data kelas (label)

$\mathrm{P}(\mathrm{H}) \quad=$ Peluang dari hipotesa $\mathrm{H}$

$\mathrm{P}(\mathrm{X}) \quad=$ Peluang dari data sampel yang di amati

$\mathrm{P}(\mathrm{X} \mid \mathrm{H}) \quad=$ Peluang data sampel $\mathrm{X}$ bila diasumsikan bahwa hipotesa benar

Rumus Naive Bayes Tipe Data Numerik (Suntoro, 2019)

Distribusi Gaussian

$$
g(x, \mu, \sigma)=\frac{1}{\sqrt{2 \pi \cdot \sigma}} \exp \frac{\frac{-(x-\mu)^{z}}{2 \sigma^{2}}}{}
$$

Mean

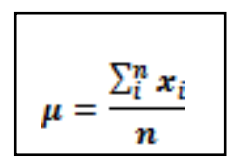

Standar Deviasi

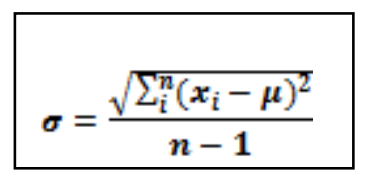


Metodologi Penelitian merupakan tahap-tahap penelitian yang sistematis untuk membantu penelitian menjadi terarah dengan baik. Berikut adalah metodologi penelitian yang dilakukan penulis:

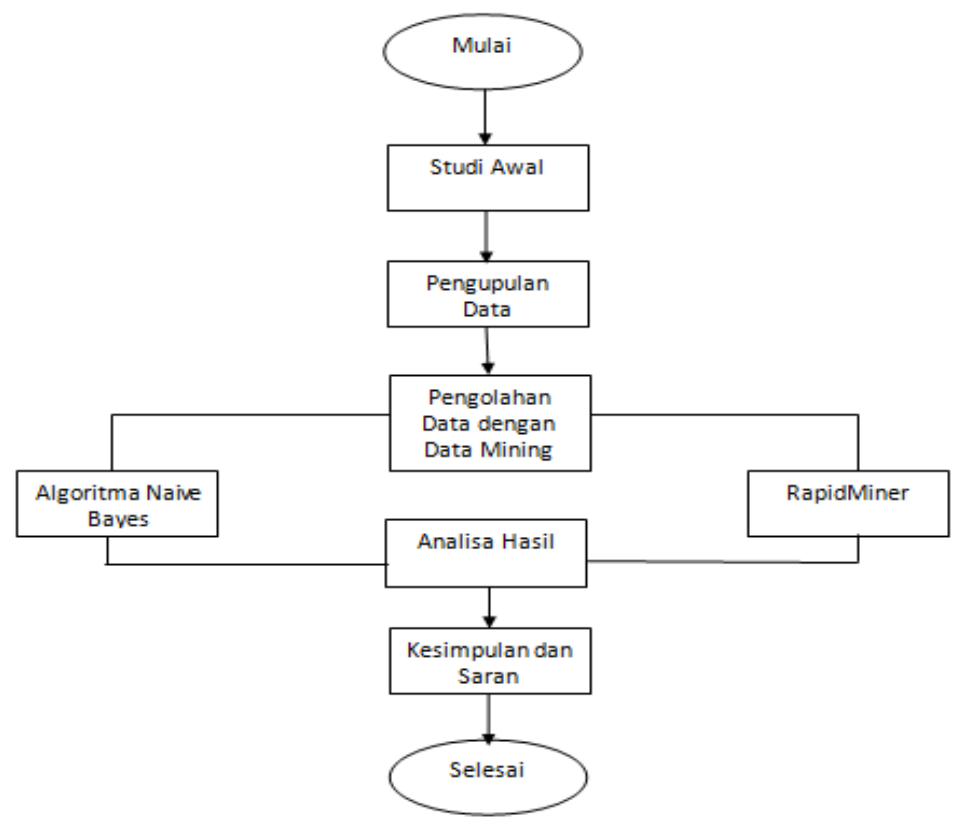

Sumber: Hasil Pengolahan Data (2020)

Gambar 1. Tahapan Penelitian

1). Studi Awal, dari penelitian ini melakukan riset di Kantor Desa Tridaya Sakti serta mencari dan mempelajari permasalahan yang terdapat pada Kantor Desa Tridaya Sakti. Mengamati situasi kemudian menentukan ruang lingkup masalah, latar belakang masalah, dan mencari literatur yang berkaitan dengan permasalahan dan bagaimana mencari solusi dari permasalahan tersebut. 2). Pengumpulan Data, dalam pengumpulan data penulis melakukan wawancara, observasi dan dokumentasi di Kantor Desa Tridaya Sakti untuk mengetahui data dan informasi yang dibutuhkan penulis, populasi dan sampel data angka kelahiran bayi 2019-2020 di Kantor Desa Tridaya Sakti. 3). Pengolahan Data Dengan Data Mining, pada tahap ini data yang sudah dikumpulkan diidenfikasi masalah yang ada dan sering terjadi di Kantor Desa Tridaya Sakti sehinga penulis dapat menganalisa masalah tersebut. Lalu data di klasifikasikan menurut variabel yang telah ditentukan menggunakan teknik Data Mining dengan algoritma Naive Bayes untuk mendapatkan hasil sebagai tujuan yang akan dicapai oleh peneliti dengan menghitung dua pola yaitu: algoritma Naive Bayes dan RapidMiner sebagai berikut: a). Pada pola perhitungan Algoritma Naive Bayes akan menghitung nilai Testing Dan Nilai Training. b). Pada pola perhitungan Aplikasi RapidMiner, maka akan menghasilkan rule nilai sebagai pembanding dari perhitungan manual algoritma Naive Bayes yang kemudian dapat dijadikan pihak Kantor Desa Tridaya Sakti sebagai pengetahuan dalam mengatur laju pertumbuhan penduduk. 4). Analisa Hasil, penulis melakukan analisi hasil dengan menggunakan Aplikasi RapidMiner dan tehnik Data Mining 
Algoritma Naive Bayes untuk menghubungkan dengan data-data yang akan diuji. 5). Kesimpulan Dan Saran, pola informasi yang dihasilkan dari proses Data Mining. Informasi yang dihasilkan dari aplikasi RapidMiner akan menampilkan dan memberikan informasi prediksi angka kelahiran bagi pada Kantor Desa Tridaya Sakti. Kantor Desa dapat mengambil keputusan yang dilakukan untuk menentukan keputusan yang baik dan tepat dalam mengetur laju pertumbuhan penduduk dengan hasil dari penelitian ini.

Metode Pengumpulan data dalam penelitian ini yang digunakan adalah: 1). Observasi Pada metode ini melakukan sebuah pengamatan langsung terhadap kegiatan pengelolaan data kependudukan yang sedang dilakuakan untuk melihat, mencatat dan mengamati setiap pencatatan data yang berkaitan dengan data kependudukan Desa Tridaya Sakti. 2). Wawancara, Pada metode ini melakukan mengumpulkan data dan mengajukan pertanyaanpertanyaan atau tanya jawab secara langsung kepada Staff dan Sekdes Kontor Desa Tridaya Sakti untuk memperoleh data yang jelas dan akurat. Sejumlah informasi yang bersifat umum yang berasal dari data masa lalu Kantor Desa Tridaya Sakti dan data yang berkaitan dengan penelitian. 3). Dokumentasi, Pada metode ini mendapatkan data kependudukan Desa Tridaya Sakti dengan mencari dan mengumpulkan data untuk menelusuri data histori berupa dokumen dan foto. metode dokumentasi guna memperlengkap data wawancara dan observasi. 4). Studi Pustaka, Pada metode ini melakukan studi pustaka dari jurnal, buku-buku referensi, literaturliteratur yang terdapat di perpustakaan dan perpustakan online lainya dan informasi lainnya yang penulis kumpulkan yang ada hubungannya dengan masalah yang diteliti.

Adapun beberapa instrumen yang dipakai penulis dalam penelitian ini adalah sebagai berikut: 1). Instrumen Pokok, Dalam penelitian kuantitatif, alat ukur atau instrumen penelitian adalah peneliti. Jadi peneliti adalah kunci instrumen dalam penelitian kualitatif (Sugiyono, 2018). Penulis sebagai instrumen dapat berhubungan dengan responden yaitu Staff dan Sekdes Kantor Desa Tridaya Sakti yang mengelola data Kepedudukan serta memahami berbagai interaksi secara langsung. 2). Instrumen Penunjang, Untuk membantu sebagai instrumen pokok, maka penulis membuat instrumen penunjang, yaitu metode wawancara dan observasi (Sugiyono, 2018). Setelah wawancara dilakukan penulis mendapatkan data-data tentang kelahiran bayi yang ada di Desa Tridaya Sakti.

Populasi dan Sampel dalam penelitian penelitian ini sebagai berikut: Populasi adalah keseluruhan kelompok orang, peristiwa, benda, atau obyek lain yang menjadi pusat perhatian peneliti untuk diteliti (Heru Mulyanto, 2010). Sedangkan Sampel adalah sebagai bagian populasi yang diharapkan dapat mewakili populasi sehingga sampel seharusnya mampu mengambarkan karakteristik populasi (Heru Mulyanto, 2010).

Populasi yang digunakan pada penelitian ini adalah dari data Kependudukan Desa Tridaya Sakti. Sampel yang digunakan pada penelitian ini adalah jumlah angka kelahiran bayi pada Desa Tridaya Sakti 10 tahun kebelakang. 
Tabel 1. Sampel Data Kependudukan Desa Tridaya Sakti 2010-2019

\begin{tabular}{ccccccc}
\hline Tahun & Laki-Laki & Perempuan & $\begin{array}{c}\text { Jumlah } \\
\text { Penduduk }\end{array}$ & $\begin{array}{c}\text { Angka } \\
\text { Pernikahan }\end{array}$ & $\begin{array}{c}\text { Angka } \\
\text { Kelahiran }\end{array}$ & WUS \\
\hline 2010 & 13.858 & 13.717 & 27.576 & 1.497 & 898 & 7.404 \\
\hline 2011 & 15.036 & 15.626 & 31.662 & 1.583 & 1.900 & 1.900 \\
\hline 2012 & 16.627 & 16.120 & 32.747 & 1.637 & 327 & 8.060 \\
\hline 2013 & 16.872 & 16.369 & 33.241 & 1.662 & 2.327 & 8.185 \\
\hline 2014 & 17.920 & 17.521 & 35.432 & 1.772 & 1.417 & 8.756 \\
\hline 2015 & 18.365 & 17.971 & 36.336 & 1.817 & 545 & 8.986 \\
\hline 2016 & 17.975 & 17.770 & 35.745 & 1.787 & 715 & 8.885 \\
\hline 2017 & 18.015 & 17.989 & 36.004 & 1.800 & 900 & 8.995 \\
\hline 2018 & 18.329 & 18.054 & 36.383 & 1.819 & 1.819 & 9.027 \\
\hline 2019 & 18.616 & 18.365 & 36.981 & 1.849 & 2.217 & 9.183 \\
\hline
\end{tabular}

Sumber: Badan Pusat Statistik Kabupaten Bekasi (2010-2019)

\section{Hasil dan Pembahasan}

Menganalisa data Kependudukan Desa Tridaya Sakti menggunakan metode Algoritma Naive Bayes dimulai dengan melakukan penentuan data-data yang akan dijadikan data Training, kemudian penulis menentukan data data yang akan di jadikan data Testing. Selanjutnya dihitung Probabilitasnya atau Prediksinya dengan Algoritma Naive Bayes.

Tabel 2. Data Training

\begin{tabular}{cccccc}
\hline Tahun & $\begin{array}{c}\text { Jumlah } \\
\text { Penduduk }\end{array}$ & $\begin{array}{c}\text { Angka } \\
\text { Pernikahan }\end{array}$ & $\begin{array}{c}\text { Angka } \\
\text { Kelahiran }\end{array}$ & WUS & Keterangan \\
\hline 2010 & 29937 & 1497 & 898 & 7404 & Tinggi \\
\hline 2011 & 31662 & 1583 & 1900 & 1900 & Tinggi \\
\hline 2012 & 32747 & 1637 & 327 & 8060 & Rendah \\
\hline 2013 & 33241 & 1662 & 2327 & 8185 & Tinggi \\
\hline 2014 & 35432 & 1772 & 1417 & 8756 & Tinggi \\
\hline 2015 & 36336 & 1817 & 545 & 8986 & Rendah \\
\hline 2016 & 35745 & 1787 & 715 & 8885 & Rendah \\
\hline 2017 & 36004 & 1800 & 900 & 8995 & Rendah \\
\hline 2018 & 36383 & 1819 & 1819 & 9027 & Tinggi \\
\hline 2019 & 36981 & 1849 & 2217 & 9183 & Tinggi
\end{tabular}

Sumber: Badan Pusat Statistik Kabupaten Bekasi (2010-2019)

Setalah dilakukan penentuan data-data yang akan dijadikan sebagai data training maka selanjutnya menentukan data yang akan dijadikan sebagai data testing seperti ditampilkan pada tabel 3 berikut. 
Tabel 3. Data Testing

\begin{tabular}{cccccc}
\hline Tahun & $\begin{array}{c}\text { Jumlah } \\
\text { Penduduk }\end{array}$ & $\begin{array}{c}\text { Angka } \\
\text { Pernikahan }\end{array}$ & $\begin{array}{c}\text { Angka } \\
\text { Kelahiran }\end{array}$ & WUS & Keterangan \\
\hline 2020 & 37803 & 1890 & 2646 & 9381 & \\
\hline
\end{tabular}

Sumber: Data Pendudukan Kantor Desa Tridaya Sakti (2020)

\subsection{Pehitungan dengan menggunakan metode Naive Bayes}

1. Menghitung Nilai $\mathrm{P}(\mathrm{Ci})$ dari Class (label) Keterangan

$\mathbf{P}(\mathbf{C i})$

$P($ Keterangan $=$ Tinggi $) \quad 6 / 10=0,6$

$P($ Keterangan $=$ Rendah $) 4 / 10=0,4$

2. Menghitung Nilai Mean

\section{Mean}

$\boldsymbol{\mu}=\frac{\sum_{i}^{n} x_{i}}{n}$

Variabel : Jumlah Penduduk, Keterangan : Tinggi

$\mu=\frac{29937+31662+33241+35432+36383+36981}{6}=33939,3$

Variabel : Jumlah Penduduk, Keterangan : Rendah

$\mu=\frac{32747+36336+35745+36004}{4}=35208$

Variabel: Angka Pernikahan, Keterangan: Tinggi

$\mu=\frac{1497+1583+1662+1772+1819+1849}{6}=1697$

Variabel : Angka Pernikahan, Keterangan : Rendah

$\mu=\frac{1637+1817+1787+1800}{4}=1760,3$

Variabel : Angka Kelahiran, Keterangan : Tinggi

$\mu=\frac{898+1900+2327+1417+1819+2217}{6}=1763,0$

Variabel : Angka Kelahiran, Keterangan : Rendah

$\mu=\frac{327+545+715+900}{4}=621,8$

Variabel : WUS, Keterangan : Tinggi 


$$
\mu=\frac{7404+7813+8185+8756+9027+9183}{6}=8394,7
$$

Variabel : WUS, Keterangan : Rendah

$$
\mu=\frac{8060+8986+8885+8995}{4}=8731,5
$$

3. Menghitung Nilai Standar Deviasi

\section{Standar Deviasi}

$$
\sigma=\frac{\sqrt{\sum_{i}^{n}\left(x_{i}-\mu\right)^{2}}}{n-1}
$$

Variabel : Jumlah Penduduk, Keterangan : Tinggi

$$
\begin{aligned}
& \sigma \\
& =\frac{\sqrt{(29937-33939,3)^{\mathrm{z}}(31662-33939,3)^{\mathrm{z}}(33241-339393,3)^{\mathrm{z}}(35432-33939,3)^{\mathrm{z}}(36383-33939,9)^{\mathrm{z}}(36981-33939,3)^{\mathrm{z}}}}{6-1} \\
& =2798
\end{aligned}
$$

Variabel : Jumlah Penduduk, Keterangan : Rendah

$$
\sigma=\frac{\sqrt{(32747-35208)^{2}+(36336-35208)^{2}+(35745-35208)^{2}+(36004-35208)^{2}}}{4-1}=1658,40
$$

Variabel : Angka Pernikahan, Keterangan: Tinggi

$$
\begin{aligned}
& =\frac{\sqrt{(1497-1697)^{2}+(1583-1697)^{2}+(1662-1697)^{2}+(1772-1697)^{2}+(1819-1697)^{2}+(1849-1697)^{2}}}{6-1} \\
& =139,88
\end{aligned}
$$

Variabel : Angka Pernikahan, Keterangan : Rendah

$$
\sigma=\frac{\sqrt{(1637-1760,3)^{z}+(1817-1760,3)^{2}+(1787-1760,3)^{2}+(1800-1760,3)^{2}}}{4-1}=83,08
$$

Variabel : Angka Kelahiran, Keterangan : Tinggi

$$
\begin{gathered}
\sigma=\frac{\sqrt{(898-1763)^{2}+(1900-1763)^{2}+(2327-1763)^{2}+(1417-1763)^{2}+(1819-1763)^{2}+(2217-1763)^{2}}}{6-1} \\
=531,80
\end{gathered}
$$

Variabel : Angka Kelahiran, Keterangan : Rendah

$$
\sigma=\frac{\sqrt{\left(327-621_{2} 8\right)^{2}+\left(545-621_{2} 8\right)^{2}+(715-621,8)^{2}+\left(900-621_{2} 8\right)^{2}}}{4-1}=244,19
$$


Variabel : WUS, Keterangan : Tinggi

$\sigma$

$=\frac{\sqrt{(7404-8394,7)^{2}+(7813-8394,7)^{2}+(8185-8394,7)^{2}+(8756-8394,7)^{2}+(9027-8394,7)^{2}+(9183-8394,7)^{2}}}{6-1}$

$=709,31$

Variabel : WUS, Keterangan : Rendah

$\sigma=\frac{\sqrt{(8060-8721,5)^{2}+(8986-8731,5)^{2}+(8885-8731,5)^{2}+\left(8995-8731_{\imath} 5\right)^{2}}}{4-1}=450,44$

4. Menghitung Nilai $P(X K \mid C i)$ untuk setiap kelas $i$

$P(X K \mid C i)$

$g(x, \mu, \sigma)=\frac{1}{\sqrt{2 \pi \cdot \sigma}} \exp \frac{-(x-\mu)^{2}}{2 \sigma^{2}}$

Variabel : Jumlah Penduduk, Keterangan : Tinggi

$g(x, \mu, \sigma)=\frac{1}{\sqrt{2 \cdot 3,14.2798}} \exp \frac{\frac{-(37803-33939,3)^{2}}{2.2798^{2}}}{2.0029076}$

Variabel : Jumlah Penduduk, Keterangan : Rendah

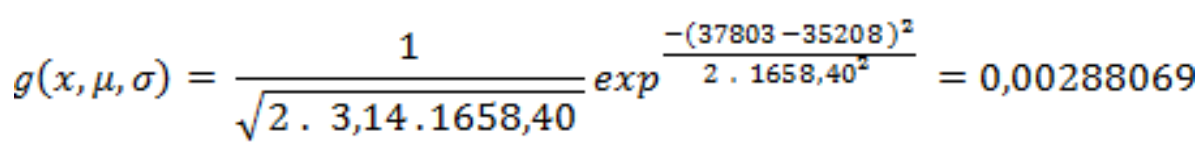

Variabel : Angka Pernikahan, Keterangan : Tinggi

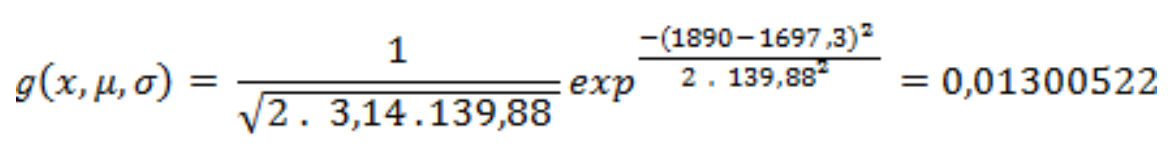

Variabel : Angka Pernikahan, Keterangan : Rendah

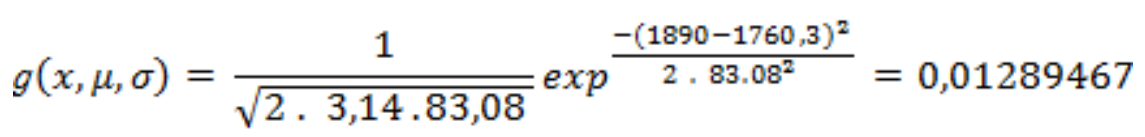

Variabel : Angka Kelahiran, Keterangan : Tinggi

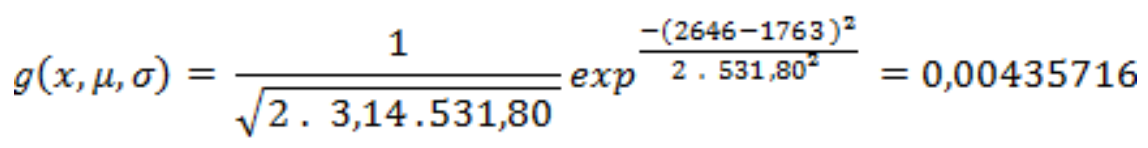

Variabel : Angka Kelahiran, Keterangan : Rendah

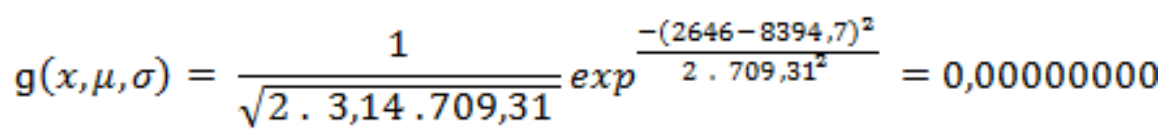

Variabel : WUS, Keterangan : Tinggi 


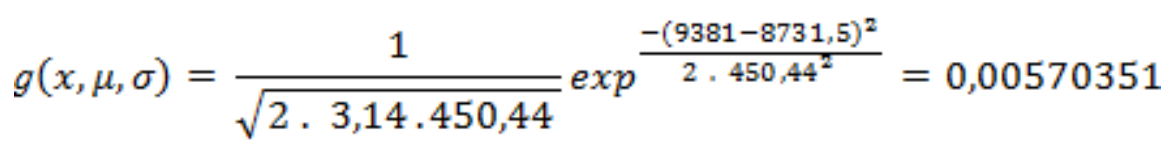

Variabel : WUS, Keterangan : Rendah

$$
g(x, \mu, \sigma)=\frac{1}{\sqrt{2 \cdot 3,14.2798}} \exp \frac{\frac{-(9381-33939,3)^{2}}{2.2798^{2}}}{2.0,00665901}
$$

5. Menghitung Nilai $P(X \mid C i)$ untuk setiao kelas (label)

$$
\mathbf{P}(\mathbf{X} \mid \mathbf{C i})
$$

$\mathrm{P}(\mathrm{X} \mid$ Keterangan $=$ "Tinggi" $)$

$=0,00290764 \times 0,01300522 \times 0,00435716 \times 0,00570351=9,39731 \mathrm{E}-10$

$\mathrm{P}(\mathrm{X} \mid$ Keterangan $=$ "Rendah" $)$

$=0,00288069 \times 0,01289467 \times 0,00000000 \times 0,00665901=7,50623 E-24$

6. Menghitung Nilai $\mathrm{P}(\mathrm{X} \mid \mathrm{Ci})^{\star} \mathrm{P}(\mathrm{Ci})$

$\mathrm{P}(\mathrm{X} \mid$ Keterangan $=$ "Tinggi" $){ }^{*} \mathrm{P}($ Keterangan $=$ "Tinggi" $)$

$=9,39731 \mathrm{E}-10 \times 0,6=5,63839 \mathrm{E}-10$

$\mathrm{P}(\mathrm{X} \mid$ Keterangan $=$ "Rendah" $){ }^{*} \mathrm{P}($ Keterangan $=$ "Rendah" $)$

$=7,50623 \mathrm{E}-24 \times 0,4=3,00249 \mathrm{E}-24$

7. Menetukan Hasil Kelas dari kasus yang telah dihitung

Berdasarkan Perhitungan akhir dengan mengalikan nilai peluang dari kasus ini, kita melihat bahwa nilai $\mathrm{P}(\mathrm{X} \mid$ Keterangan $=$ "Tinggi") lebih tinggi dari $\mathrm{P}(\mathrm{X} \mid$ Keterangan $=$ "Rendah"), keterangan "Tinggi" 5,63839E-10 banding keterangan "Rendah" 3,00249E24 maka kelas (label) keterangn"Tinggi".

Tabel 4. Hasil Perhitungan Naive Bayes

\begin{tabular}{cccccc}
\hline Tahun & $\begin{array}{c}\text { Jumlah } \\
\text { Penduduk }\end{array}$ & $\begin{array}{c}\text { Angka } \\
\text { Pernikahan }\end{array}$ & $\begin{array}{c}\text { Angka } \\
\text { Kelahiran }\end{array}$ & WUS & Keterangan \\
\hline 2020 & 37803 & 1890 & 2646 & 9381 & Tinggi \\
\hline
\end{tabular}

Sumber: Hasil Pengolahan Data (2020)

8. Hasil Prediksi menggunakan Aplikasi RapidMiner

Hasil dari perhitungan Aplikasi RapidMiner menunjukan Prediksi data Testing yaitu label keterangan "Tinggi", berarti hasil prediksi Angka Kelahiran Bayi di Desa Tridaya Sakti tahun 2020 adalah Angka Kelahirannya Tinggi. 


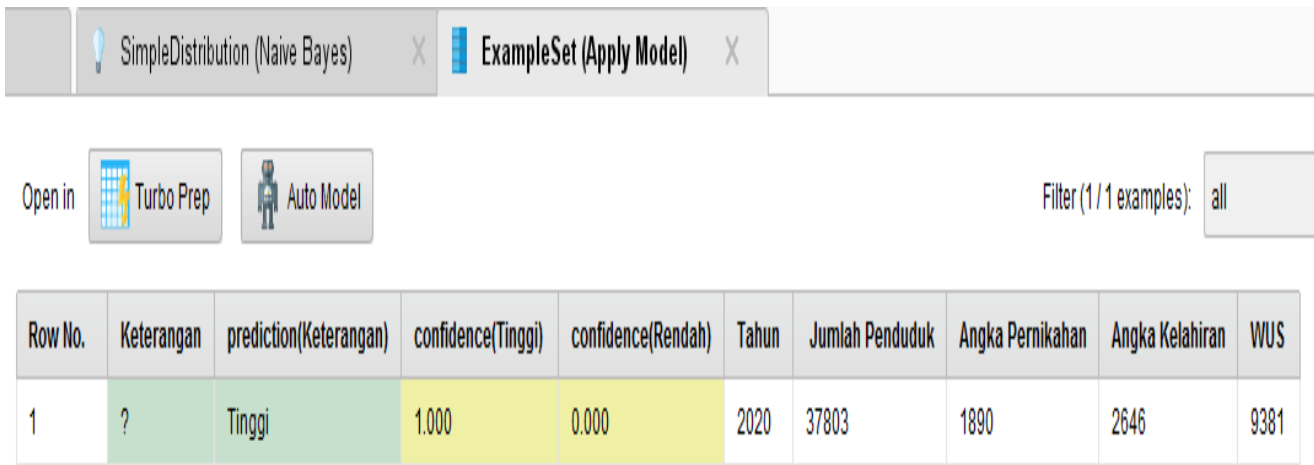

Sumber : Hasil Pengolahan Data (2020)

Gambar 2. Hasil Prediksi Data Testing dari Aplikasi RapidMiner

Hasil perhitungan parameter dari setiap atribut pada data training dengan Aplikasi RapidMiner menggunakan algoritma Naive Bayes, Parameter yang digunakan adalah Mean dan Standar Deviation.

\begin{tabular}{|l|l|l|l|}
\hline Attribute & Parameter & Tinggi & Rendah \\
\hline Tahun & mean & 2014.167 & 2015 \\
\hline Tahun & standard deviation & 3.656 & 2.160 \\
\hline Jumlah Penduduk & mean & 33939.333 & 35208 \\
\hline Jumlah Penduduk & standard deviation & 2797.995 & 1658.402 \\
\hline Angka Pernikahan & mean & 1697 & 1760.250 \\
\hline Angka Pernikahan & standard deviation & 139.881 & 83.080 \\
\hline Angka Kelahiran & mean & 1763.333 & 621.750 \\
\hline Angka Kelahiran & standard deviation & 532.142 & 244.190 \\
\hline WUS & mean & 8394.667 & 8731.500 \\
\hline WUS & standard deviation & 709.309 & 450.436 \\
\hline
\end{tabular}

Sumber: Hasil Pengolahan Data (2020)

Gambar 3. Hasil Perhitungan Parameter dari Aplikasi RapidMiner

\section{Kesimpulan}

Data Mining sangat berguna untuk memprediksi angka kelahiran dimasa yang akan datang. Data Mining merupakan metode yang dapat membantu pemerintah daerah dalam menemukan informasi penting dari gudang data yang selama ini tidak diketahui manfaatnya. Hasil prediksi angka kelahiran bayi di Desa Tridaya Sakti tahun 2020 ini dapat digunakan Kantor Desa Tridaya Sakti untuk membantu petugas kependudukan dalam melakukan evaluasi laporan data penduduk dan juga sebagai acuan penekan jumlah angka kelahiran yang akan datang. Algoritma Naive Bayes dapat menghitung Probabilitas dari dataset. Hasil prediksi angka kelahiran 2020 label keterangan $P(X \mid$ Keterangan = "Tinggi") =5,63839E-10. Dari hasil penelitian ini Kantor Desa Tridaya Sakti dapat mengambil langkah atau tindakan dalam 
menekan angka kelahiran bayi dengan lebih meningkatkan kegiatan sosialisasi dan pembinaan Keluarga Berencana (KB).

\section{Daftar Pustaka}

Dicky Nofriansyah, G. W. N. (2015). Algoritma Data Mining dan Pengujian. Deepublish.

Idris, M. (2019). Implementasi Data Mining Dengan Algoritma Naïve Bayes Untuk Memprediksi Angka Kelahiran. Jurnal Pelita Informatika, 18, 160-167.

Kelahiran, J. A. (2017). Jurusan Teknik Informatika, Fakultas Teknik, Universitas Maritim Raja Ali Haji. 1-6.

Rochaida, E. (2016). Dampak Pertumbuhan Penduduk Terhadap Pertumbuhan Ekonomi Dan Keluarga Sejahtera Di Provinsi Kalimantan Timur. Forum Ekonomi, 18(1), 14-24. http://ejournal.stieibbi.ac.id/index.php/jmb/article/view/59/23

Sugiyono, P. D. (2018). Metode Penelitian Kuantitatif, kealitatif dan R\&D. ALFABETA CV.

Suntoro, J. (2019). Data Mining Algoritma dan Implementasi dengan Pemrograman PHP. PT Elex Media Komputindo.

Syahra, Y., Santoso, I., Kustini, R., \& Pembahasan, A. D. A. N. (2019). Implementasi Data Mining Untuk Prediksi Angka Kelahiran Bayi Pada Desa Sibolangit Menggunakan Multi Regresi. Seminar Nasional Sains \& Teknologi Informasi (SENSASI), 1, 687-690. 